\title{
Improving quality and quantity of mungbean plant via foliar application of plant growth regulators in sandy soil conditions
}

\author{
Mohamed Farouk El Karamany', Mervat Shamoon Sadak ${ }^{2 *}$ and Bakry Ahmed Bakry ${ }^{1}$
}

\begin{abstract}
Background: Two field experiments were carried out in Researches and Production Station of National Research Centre, Al-Nubaria District, Al Behaira Governorate, Egypt. To study the effect of indole acetic acid (IAA) and /or gibberellic acid $\left(\mathrm{GA}_{3}\right)$ on growth, photosynthetic pigments, yield, and chemical composition of mungbean seeds, different concentrations of IAA and/or $\mathrm{GA}_{3}$ were used.

Results: Results indicated that all treatments caused significant increases in morphological criteria, biochemical parameters, and yield of mungbean plants. IAA or $\mathrm{GA}_{3}$ with $50 \mathrm{mg} / \mathrm{l}$ concentration recorded the best values growth photosynthetic pigments, as well as, endogenous auxins, $\mathrm{GA}_{3}$, and cytokinins. Interaction of IAA $50 \mathrm{mg} / \mathrm{I}+\mathrm{GA} \mathrm{A}_{3} 50$ $\mathrm{mg} / \mathrm{l}$ gave the most effective treatment. The superiority of treatment IAA $50 \mathrm{mg} / \mathrm{l}, \mathrm{GA} 350 \mathrm{mg} / \mathrm{l}$, and interaction of IAA $50 \mathrm{mg} / \mathrm{l}+\mathrm{GA}_{3} 50 \mathrm{mg} / \mathrm{l}$ recorded the same trend due to yield and yield components in characters' plant height, pods no./plant, pods weight/plant, seeds no./pod, seed yield, straw yield, biological yield, total carbohydrates, protein in seeds (\%), and $\mathrm{N}$ in seeds (\%).

Conclusion: It could be concluded that foliar spray of $50 \mathrm{mg} / \mathrm{IAA}+50 \mathrm{mg} / \mathrm{I} \mathrm{GA} 3$ was the most effective treatment on increasing growth and yield of mungbean.
\end{abstract}

Keywords: Mungbean, IAA, GA 3 , Photosynthetic pigments, Chemical composition

\section{Introduction}

Mungbean (Vigna radiata L. Wilczek) is a summer pulse crop with short duration (70-90 days) and double use (forage and seed) and high nutritive value. Forage contains $12-18 \%$ protein but seeds contain $22-28 \%$ protein, $60-65 \%$ carbohydrates, $1-1.5 \%$ fats, $3.5-4.5 \%$ ash (El Karamany 2006). Mungbean is commonly used in cooking using green and mature pods. Sprouts are rich in vitamins and amino acids also, in broilers' diets as untraditional feeding stuff or its husks as crop by-products for feeding rabbits (Omer et al. 2017). Plant growth regulators (PGRs) are known to influence plant growth and development at very low concentrations.

\footnotetext{
* Correspondence: mervat_sh24@yahoo.com

${ }^{2}$ Botany Department, Agricultural and Biological Division, Agricultural and

Biological Division, National Research Centre, Giza 12622, Egypt

Full list of author information is available at the end of the article
}

Moreover, the response of the plant to PGRs may vary with species, varieties, environmental conditions, physiological and nutritional status, stage of development and endogenous hormonal balance (Naeem et al. 2004) delays senescence (Shah 2007). Plants have the ability to store excessive amounts of exogenously supplied hormones in the form of reversible conjugates which release active hormone when the plants need them during the growth period (Davies 2004). Ammanullah et al. (2010) mentioned that plant growth substances are known to enhance the source-sink relationship and stimulate the translocation of photo-assimilates to sink thereby helping in effective flower formation, fruit, and seed development and ultimately enhancing the productivity of crops. Various plant growth regulators which regulate growth under normal or stress conditions are auxins. Generally, auxins are the best hormones for use because 
they are non-toxic to plants over a wide range of concentration and effective in promoting the root system of a large number of plant species. Auxins might regulate cell elongation, cell division, tissue swelling, formation of adventitious roots, callus initiation, induction of embryogenesis, and promoting cell wall loosening at very low concentrations (Taiz and Zeiger 2006). The principal auxin in plants is indole-3-acetic acid (IAA) that produced mainly in the shoot apex bud and young leaves of plants. Other meristematic tissues, flowers, fruits, and young seeds have also been shown to be sites of this hormone production (Sadak et al. 2013). Gibberellins (GAs) are the most important natural growth regulators and generally involved in the growth and development of different plant. They control seed germination, leaf expansion, stem elongation, and flowering (Magome et al. 2004 and Kumar et al. 2018). Gibberellic acid (GA) is used to induce great changes in the growth characters, chemical composition, and yield criteria of the plant. Choudhury et al. (2013) stated that $\mathrm{GA}_{3}$ treatment increased the growth and yield of the tomato plant.

So, this study is an attempt to improve plant growth and yield quantity and quality of mungbean plant under new reclaimed sandy soil, through improving some physiological and biochemical processes by using naturally occurring substances IAA and $\mathrm{GA}_{3}$.

\section{Materials and methods}

Two field experiments were carried out during summer seasons of 2016 and 2017 in Researches and Production Station of National Research Centre (NRC), Al-Nubaria District, Al Behaira Governorate, Egypt. The experimental soil before sowing was analyzed according to Chapman and Pratt 1978. Soil texture was sandy, and its characteristics are shown in Table 1.

Seeds of mungbean were soaked for $12 \mathrm{~h}$ in different concentrations of bioregulator indole acetic acid (IAA) and/or gibberellic acid $\left(\mathrm{GA}_{3}\right)$ with different concentrations as follows:

(1) Control (IAA $0.0 \mathrm{mg} / \mathrm{l}, \mathrm{GA}_{3} 0.0 \mathrm{mg} / \mathrm{l}$ ); (2) IAA 25 mg/l; (3) IAA $50 \mathrm{mg} / \mathrm{l}$; (4) $\mathrm{GA}_{3} 25 \mathrm{mg} / \mathrm{l}$; (5) $\mathrm{GA}_{3} 50 \mathrm{mg} / \mathrm{l}$; (6) IAA $25 \mathrm{mg} / \mathrm{l}+\mathrm{GA}_{3} 25 \mathrm{mg} / \mathrm{l}$; (7) IAA $25 \mathrm{mg} / \mathrm{l}+\mathrm{GA}_{3} 50$ $\mathrm{mg} / \mathrm{l}$; (8) IAA $50 \mathrm{mg} / \mathrm{l}+\mathrm{GA}_{3} 25 \mathrm{mg} / \mathrm{l}$; and (9) IAA $50 \mathrm{mg} /$ $\mathrm{l}+\mathrm{GA}_{3} 50 \mathrm{mg} / \mathrm{l}$

The experiment design was complete randomized block design in three replicates. Area of each plot was $10.5 \mathrm{~m}^{2}$ ( 6 rows $\times 0.50 \mathrm{~m}$ width $\times 3.5 \mathrm{~m}$ length). Seeds of mungbean variety (kawmy-1) inoculated with a specific strain of bacteria and hand seeded in hills $0.30 \mathrm{~m}$ between ( 2 seeds/hill) on the 15th and 17th of June in both seasons. The soil was immediately irrigated after sowing using sprinkler irrigation system. Fertilization of NPK at a rate of $(33: 32: 24) /$ feddan $\left(4200 \mathrm{~m}^{2}\right)$ in the form of ammonium nitrate $33 \% \mathrm{~N}$; superphosphate $15.5 \% \mathrm{P}_{2} \mathrm{O}_{5}$ and potassium sulfate $48 \% \mathrm{~K}_{2} \mathrm{O}$. Other cultural practices were done due to those recommended for mungbean.

Plant samples were taken after 60 DAS from sowing random sample of $0.5 \times 0.5 \mathrm{~m}^{2}$ was cut for determination of growth criteria (shoot length, branches, and leaves no/plant, leaves fresh dry wt/plant) and estimation of some biochemical parameters in leaves of the plant such as photosynthetic pigments and endogenous phytohormones. At harvest (90 DAS) 10 plants from each central plot were randomly taken for yield components measure but the whole yield of each plot $\left(10.5 \mathrm{~m}^{2}\right)$ was harvested for character measure per feddan and then the following characters were determined: (1) plant height $(\mathrm{cm})$; (2) pods no./plant; (3) pods weight/plant; (4) seeds no./pod; (5) seed yield (ton/feddan); (6) straw yield (ton/feddan); (7) biological yield (ton/feddan); (8) total carbohydrates (\%); (9) protein in seeds (\%); (10) $\mathrm{N}$ in seeds (\%).

- Feddan $=$ fed. is a local unit area equal $\left(4200 \mathrm{~m}^{2}\right)$.

\section{Measurements}

Photosynthetic pigments content as Lichtenthaler and Buschmann (2001). Based on the results of the first season (2015), the most promising treatments were selected for the determination of endogenous regulators. These endogenous growth hormones, namely, auxins, gibberellic acid, abscisic acid (ABA), and cytokinins were extracted according to Wasfy and Orrin (1975). IAA, GA, and $\mathrm{ABA}$ contents were determined by gas-liquid chromatography (GLC) according to the method described by Wasfy and Orrin (1975) and cytokinin content was determined by high-performance liquid chromatography (HPLC) according to the method described by Muller and Hilgenberg (1986). The phenol-sulfuric acid method was used for the determination of total carbohydrates (Dubois et al. 1956). Nitrogen and protein contents were determined with micro Kjeldahl's apparatus according to the method described by Miller and Houghton, (1945). Crude protein was determined according to Bradford (1975) (multiplying nitrogen contents by 5.75).

Table 1 Mechanical and chemical analysis of experimental soil

\begin{tabular}{lccccccccc}
\hline Sand $\%$ & Silt \% & Clay \% & pH & Organic matter, \% & $\mathrm{CaCO}_{3} \%$ & E.C. dS/m & Soluble N, ppm & Available P, ppm & Exchangeable K, ppm \\
\hline 91.2 & 3.7 & 5.1 & 7.3 & 0.3 & 1.4 & 0.3 & 8.1 & 3.2 & 20
\end{tabular}

Temperature averages $\left({ }^{\circ} \mathrm{C}\right.$ ) during the trial period were June 25.60 , July 25.80 , and August 27.2 . Humidity average (\%): June $76.3 \%$, July $77.0 \%$, and August $76.9 \%$, respectively 


\section{Statistical analysis}

The obtained results were subjected to statistical analysis of variance according to the method described by Snedecor and Cochran (1990), since the trend was similar in both seasons the homogeneity test Bartlet's equation was applied and the combined analysis of the two seasons was calculated using SAS software version $9.3^{2}$. Means were compared by using the least significant difference (LSD) at 5\% levels of probability.

\section{Results}

\section{Changes in growth criteria}

Data of the vegetative growth criteria of mungbean under sandy soil are presented in (Table $2 \mathrm{a}-\mathrm{c}$ ). The obtained results show that application of the two growth regulators (IAA and $\mathrm{GA}_{3}$ ) individually (Table $2 \mathrm{a}, \mathrm{b}$ ) or in combination

Table 2 Effect of IAA (a) or $\mathrm{GA}_{3}$ (b), and IAA + GA 3 (c) $(0,25$, and $50 \mathrm{mg} / \mathrm{l})$ on growth parameters of mungbean plants grown under sandy soil

\begin{tabular}{|c|c|c|c|c|c|c|}
\hline \multicolumn{7}{|l|}{$a-\mid A A$} \\
\hline \multirow{2}{*}{\multicolumn{2}{|c|}{ Characters }} & \multicolumn{3}{|c|}{ IAA (mg/l) } & \multirow{2}{*}{\multicolumn{2}{|c|}{ LSD 5\% }} \\
\hline & & 0 & 25 & 50 & & \\
\hline \multicolumn{2}{|c|}{ Shoot length } & 35.50 & 41.33 & 42.50 & \multicolumn{2}{|l|}{0.67} \\
\hline \multicolumn{2}{|c|}{ Branches no. } & 1.67 & 1.33 & 1.33 & \multicolumn{2}{|c|}{ Non-significant } \\
\hline \multicolumn{2}{|c|}{ Leaves no. } & 4.50 & 5.00 & 5.33 & \multicolumn{2}{|l|}{0.39} \\
\hline \multicolumn{2}{|c|}{ Leaves fresh wt } & 4.90 & 5.51 & 6.89 & \multicolumn{2}{|l|}{0.21} \\
\hline \multicolumn{2}{|c|}{ Leaves dry wt } & 0.79 & 0.89 & 1.11 & \multicolumn{2}{|l|}{0.03} \\
\hline \multicolumn{7}{|c|}{$b-G A_{3}$} \\
\hline \multirow{2}{*}{\multicolumn{2}{|c|}{ Characters }} & \multicolumn{3}{|c|}{$\mathrm{GA}(\mathrm{mg} / \mathrm{l})$} & \multirow{2}{*}{\multicolumn{2}{|c|}{ LSD 5\% }} \\
\hline & & 0 & 25 & 50 & & \\
\hline \multicolumn{2}{|c|}{ Shoot length } & 34.50 & 41.00 & 43.83 & \multicolumn{2}{|l|}{0.67} \\
\hline \multicolumn{2}{|c|}{ Branches no. } & 1.17 & 1.67 & 1.50 & \multicolumn{2}{|l|}{0.33} \\
\hline \multicolumn{2}{|c|}{ Leaves no. } & 4.33 & 5.17 & 5.33 & \multicolumn{2}{|l|}{0.39} \\
\hline \multicolumn{2}{|c|}{ Leaves fresh wt } & 4.62 & 5.70 & 6.99 & \multicolumn{2}{|l|}{0.22} \\
\hline \multicolumn{2}{|c|}{ Leaves dry wt } & 0.74 & 0.92 & 1.12 & \multicolumn{2}{|l|}{0.04} \\
\hline \multicolumn{7}{|c|}{$c-I A A+G A_{3}$} \\
\hline $\begin{array}{l}\text { IAA } \\
(\mathrm{mg} / \mathrm{l})\end{array}$ & $\begin{array}{l}\mathrm{GA}_{3} \\
(\mathrm{mg} / \mathrm{l})\end{array}$ & $\begin{array}{l}\text { Shoot } \\
\text { length }\end{array}$ & $\begin{array}{l}\text { Branches } \\
\text { no. }\end{array}$ & $\begin{array}{l}\text { Leaves } \\
\text { no. }\end{array}$ & $\begin{array}{l}\text { Leaves } \\
\text { fresh wt }\end{array}$ & $\begin{array}{l}\text { Leaves } \\
\text { dry wt }\end{array}$ \\
\hline \multirow[t]{3}{*}{0} & 0 & 30.00 & 1.00 & 3.50 & 3.07 & 0.49 \\
\hline & 25 & 37.50 & 2.00 & 5.00 & 4.97 & 0.80 \\
\hline & 50 & 39.00 & 2.00 & 5.00 & 6.68 & 1.08 \\
\hline \multirow[t]{3}{*}{25} & 0 & 35.50 & 1.00 & 4.00 & 4.62 & 0.74 \\
\hline & 25 & 42.00 & 1.50 & 5.50 & 5.14 & 0.83 \\
\hline & 50 & 46.50 & 1.50 & 5.50 & 6.76 & 1.09 \\
\hline \multirow[t]{3}{*}{50} & 0 & 38.00 & 1.50 & 5.50 & 6.16 & 0.99 \\
\hline & 25 & 43.50 & 1.50 & 5.00 & 6.99 & 1.13 \\
\hline & 50 & 46.00 & 1.00 & 5.50 & 7.53 & 1.21 \\
\hline LSD 5\% & & 1.15 & 0.58 & 0.68 & 0.37 & 0.50 \\
\hline
\end{tabular}

(Table 2c) caused significant increases in the growth criteria (shoot length $(\mathrm{cm})$, branches and leaves no./plant, leaves fresh dry wt/plant (g)) of mungbean plant as compared with that of the control plants. The highest values of growth criteria were obtained from the application of 50 $\mathrm{mg} / \mathrm{l} \mathrm{IAA}+50 \mathrm{mg} / \mathrm{l} \mathrm{GA} \mathrm{G}_{3}$ treatment as compared with those obtained from the control and other treatments. Regarding IAA treatments individually, it was found that treating mungbean by $50 \mathrm{mg} / \mathrm{l}$ IAA was the most effective treatment. Also, the most effective $\mathrm{GA}_{3}$ treatment individually was $50 \mathrm{mg} / \mathrm{l}$.

\section{Changes in photosynthetic pigments}

The changes in chlorophyll a, chlorophyll b, carotenoids, and total photosynthetic pigments in response to IAA and/or $\mathrm{GA}_{3}$ treatments are shown in Table $3 \mathrm{a}-\mathrm{c}$. Data reveal that IAA and/or $\mathrm{GA}_{3}$ treatments caused significant increases in photosynthetic pigment constituents as compared with control. The highest values of photosynthetic

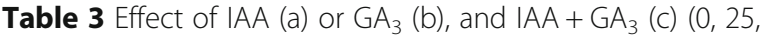
and $50 \mathrm{mg} / \mathrm{l}$ ) on photosynthetic pigments ( $\mu \mathrm{g} / 100 \mathrm{~g}$ fresh $\mathrm{wt}$ ) of mungbean plants grown under sandy soil

\begin{tabular}{|c|c|c|c|c|c|}
\hline \multicolumn{6}{|l|}{$a-I A A$} \\
\hline \multirow{2}{*}{\multicolumn{2}{|c|}{ Characters }} & \multicolumn{3}{|c|}{ IAA (mg/l) } & \multirow[t]{2}{*}{ LSD 5\% } \\
\hline & & 0 & 25 & 50 & \\
\hline \multicolumn{2}{|l|}{ Chlo a } & 797.64 & 865.42 & 896.64 & 6.40 \\
\hline \multicolumn{2}{|l|}{ Chlo b } & 356.09 & 390.01 & 400.28 & 3.20 \\
\hline \multicolumn{2}{|l|}{ Carotenoids } & 250.77 & 272.10 & 281.89 & 2.20 \\
\hline \multicolumn{2}{|c|}{ Total pigments } & 1404.49 & 1527.52 & 1578.81 & 8.30 \\
\hline \multicolumn{6}{|l|}{$b-G_{3}$} \\
\hline \multirow{2}{*}{\multicolumn{2}{|c|}{ Characters }} & \multicolumn{3}{|c|}{$\mathrm{GA}(\mathrm{mg} / \mathrm{l})$} & LSD 5\% \\
\hline & & 0 & 25 & 50 & \\
\hline \multicolumn{2}{|l|}{ Chlo a } & 797.47 & 859.29 & 902.93 & 8.24 \\
\hline \multicolumn{2}{|l|}{ Chlo b } & 356.01 & 383.61 & 406.76 & 4.80 \\
\hline \multicolumn{2}{|l|}{ Carotenoids } & 250.71 & 270.15 & 283.89 & 2.80 \\
\hline \multicolumn{2}{|c|}{ Total pigments } & 1404.19 & 1513.04 & 1593.58 & 8.40 \\
\hline \multicolumn{6}{|c|}{$c-I A A+G A_{3}$} \\
\hline IAA (mg/l) & $\mathrm{GA}_{3}(\mathrm{mg} / \mathrm{l})$ & Chlo a & Chlo b & Carotenoids & Total pigments \\
\hline \multirow[t]{3}{*}{0} & 0 & 750.27 & 334.94 & 235.87 & 1321.08 \\
\hline & 25 & 805.82 & 359.74 & 253.34 & 1418.90 \\
\hline & 50 & 836.82 & 373.58 & 263.08 & 1473.49 \\
\hline \multirow[t]{3}{*}{25} & 0 & 803.82 & 358.85 & 252.71 & 1415.38 \\
\hline & 25 & 868.78 & 387.85 & 273.13 & 1529.75 \\
\hline & 50 & 923.66 & 423.33 & 290.45 & 1637.44 \\
\hline \multirow[t]{3}{*}{50} & 0 & 838.32 & 374.25 & 263.56 & 1476.13 \\
\hline & 25 & 903.27 & 403.24 & 283.97 & 1590.48 \\
\hline & 50 & 948.32 & 423.36 & 298.14 & 1669.82 \\
\hline \multicolumn{2}{|l|}{ LSD 5\% } & 6.80 & 4.20 & 2.40 & 4.60 \\
\hline
\end{tabular}


pigments were recorded by treatment of $50 \mathrm{mg} / \mathrm{l} \mathrm{IAA}$ $+50 \mathrm{mg} / \mathrm{l} \mathrm{GA}$.

\section{Endogenous phytohormones}

Based on the obtained results of the first season $50 \mathrm{mg} / \mathrm{l}$ $\mathrm{GA}_{3}$ and $50 \mathrm{mg} / \mathrm{l} \mathrm{IAA}$ as individual treatment as well as $50 \mathrm{mg} / \mathrm{l} \mathrm{GA} 3+50 \mathrm{mg} / \mathrm{l}$ IAA as mixture treatment were selected to determine the endogenous phytohormones content as shown in Table 4. Individual treatments of $50 \mathrm{mg} / \mathrm{l}$ of both $\mathrm{GA}_{3}$ or IAA as well as combined treatment of $50 \mathrm{mg} / \mathrm{l} \mathrm{GA}_{3}+50 \mathrm{mg} / \mathrm{l}$ IAA caused increases in IAA, $\mathrm{GA}_{3}$, and cytokinin (zeatin) contents concomitant with the decline in ABA contents of mungbean plants as compared with control plant. Using the combined treatment of both $\mathrm{GA}_{3}$ + IAA with $50 \mathrm{mg} / \mathrm{l}$ was the most effective treatment as shown in Table 4.

\section{Yield and yield attributes}

Data in Table $5 \mathrm{a}-\mathrm{c}$ indicated that IAA and/or $\mathrm{GA}_{3}$ treatments caused increases in yield and yield attributes (plant height, pods no./plant, pods wt/plant, seeds no./pod, seed wt, straw, and biological yield/feddan) of mungbean. Furthermore, the highest values of yield were obtained from the application of $50 \mathrm{mg} / \mathrm{l} \mathrm{IAA}+50 \mathrm{mg} \mathrm{GA}_{3}$. Soaking mungbean seeds in different concentrations of IAA or $\mathrm{GA}_{3}$ individually increased markedly yield of mungbean. These increases in yield attributes could be a reflection of the promotive effect of growth regulators on plant growth (Table 2) and marked increases in the photosynthetic pigments content and endogenous phytohormones (Tables 3 and 4), which could lead to increase in photo-assimilates and greater transfer of assimilates to the yield (Table 5).

\section{Chemical composition of the yielded seeds}

Data in Table $5 \mathrm{a}-\mathrm{c}$ reveals that IAA and $\mathrm{GA}_{3}$ treatments significantly increased total carbohydrate, protein, and nitrogen contents in the yielded seeds of the mungbean plant compared with the control plants. Treatment of $50 \mathrm{mg} / \mathrm{l} \mathrm{IAA}+50 \mathrm{mg} / \mathrm{l} \mathrm{GA} 3$ was the most effective treatment as it caused the highest total carbohydrate and protein contents of the yielded seeds. These results agree that treatments had an enhancement effect on growth as reported in some of the findings of Ibrahim et al. (2007),

Table 4 Effect of IAA and/or $\mathrm{GA}_{3}(0$ and $50 \mathrm{mg} / \mathrm{l})$ on endogenous phytohormones ( $\mu \mathrm{g} / 100 \mathrm{~g}$ Fresh wt) of mungbean plants grown under sandy soil

\begin{tabular}{|c|c|c|c|c|c|}
\hline \multicolumn{2}{|c|}{ Treatment } & \multirow[t]{2}{*}{ IAA } & \multirow[t]{2}{*}{$\mathrm{GA}_{3}$} & \multirow[t]{2}{*}{$A B A$} & \multirow[t]{2}{*}{ Zeatin } \\
\hline IAA & $\mathrm{GA}_{3}$ & & & & \\
\hline 0 & 0 & 32.52 & 57.35 & 23.05 & 36.24 \\
\hline 0 & 50 & 68.35 & 71.52 & 16.24 & 72.52 \\
\hline 50 & 0 & 72.52 & 68.52 & 16.52 & 75.52 \\
\hline 50 & 50 & 87.65 & 92.52 & 10.65 & 98.32 \\
\hline
\end{tabular}

Sadak et al. (2013), and Choudhury et al. (2013) on faba bean for IAA treatments.

\section{Discussion}

Foliar treatment of IAA and/or $\mathrm{GA}_{3}$ caused marked increases in growth parameters of mungbean (Table $2 a-c$ ). These increments are similar to those reported by Kaya et al. (2013) and Sadak et al. (2013) on different plant species. IAA or $\mathrm{GA}_{3}$ as of the major two plant growth regulators IAA belongs to auxins and $\mathrm{GA}_{3}$ belongs to Gibberellins were reported to augment growth and development of plants by stimulating a wide range of processes, including cell elongation and tissue growth, phototropism and gravitropism, apical dominance, lateral root initiation, differentiation of vascular tissues, embryogenesis, senescence, fruit setting, and ripening (MacDonald 1997 and Taiz and Zeiger 2006). In addition, the promoting effect of IAA may be attributed to enlarging leaves and increasing photosynthetic activities as obtained in Table 3a-c (Naeem et al. 2004), increasing cell division and accumulation of building units accompanied by greater polysaccharides and total carbohydrates content (Sadak et al. 2013). Moreover, Atteya et al. (2018) confirmed the improving role of Gibberellic acid on growth characters of Simmondsia chinensis plant.

Table $3 \mathrm{a}-\mathrm{c}$ revealed the positive effect of IAA and/or $\mathrm{GA}_{3}$ on photosynthetic pigments constituents. These obtained results of different treatments are similar to those obtained by Kaya et al. (2013) on maize. Jacobs (1979) found that IAA presumably acts as a coenzyme in the metabolism of higher plants, thus it plays an important role in the formation of the photosynthetic pigments. These increases in pigments content may be attributed to the promotion of pigments synthesis and/or retardation of its degradation. Regarding gibberellic acid, Atteya et al. (2018) confirmed the enhancing role of gibberellic acid on photosynthetic pigments of Simmondsia chinensis plant.

IAA and/or $\mathrm{GA}_{3}$ foliar treatment induced marked increases in IAA, $\mathrm{GA}_{3}$, and cytokinins, meanwhile decreased ABA contents of mungbean plants. These obtained data are similar to those obtained by El-Saeid et al. (2010), Barakat (2011), and Sadak et al. (2013) on cowpea, wheat, and faba bean plant. These increases in different growth bioregulators could be attributed to the enhancement in their biosynthesis and/or decreases in their degradation (Taiz and Zeiger 2006). Different treatments improve endogenous phytohormones via decreasing activity of their degrading enzymes (Letham et al. 1978). Whereas the decreases in ABA contents might be referred to the shift of the isopentenyl pyrophosphate which is the common precursor into cytokinin and/or gibberellins biosynthesis instead of ABA (Hopkins and Hünter 2004. 
Table 5 Effect of IAA (a) or GA $(b)$, and IAA $+G_{3}$ (c) $(0,25$, and 50 mg/l) on yield, yield attributes, and chemical values of mungbean plant grown under sandy soil

\begin{tabular}{|c|c|c|c|c|c|c|c|c|c|c|c|}
\hline \multicolumn{12}{|l|}{ a-IAA } \\
\hline \multirow{2}{*}{\multicolumn{5}{|c|}{ Characters }} & \multicolumn{4}{|c|}{ IAA (mg/l) } & \multicolumn{3}{|l|}{ LSD 5\% } \\
\hline & & & & & \multicolumn{2}{|l|}{0} & 25 & 50 & & & \\
\hline \multicolumn{5}{|c|}{ Plant height } & \multicolumn{2}{|l|}{47.08} & 52.33 & 55.17 & \multicolumn{3}{|l|}{0.62} \\
\hline \multicolumn{5}{|c|}{ Pods no/plant } & \multicolumn{2}{|l|}{6.67} & 7.50 & 8.17 & \multicolumn{3}{|l|}{0.32} \\
\hline \multicolumn{5}{|c|}{ Pods wt/plant } & \multicolumn{2}{|l|}{3.77} & 4.40 & 5.43 & \multicolumn{3}{|l|}{0.24} \\
\hline \multicolumn{5}{|c|}{ Seeds no/pod } & \multicolumn{2}{|l|}{8.50} & 9.00 & 9.50 & \multicolumn{3}{|c|}{ Non-significant } \\
\hline \multicolumn{5}{|c|}{ Seed yield (ton/fed) } & \multicolumn{2}{|l|}{1.88} & 2.54 & 2.87 & \multicolumn{3}{|l|}{0.36} \\
\hline \multicolumn{5}{|c|}{ Straw yield (ton/fed) } & \multicolumn{2}{|l|}{4.45} & 4.82 & 5.27 & \multicolumn{3}{|l|}{0.22} \\
\hline Biolog & al yield (ton/ & & & & 6.33 & & 7.36 & 8.15 & \multicolumn{3}{|l|}{0.20} \\
\hline Total c & rbohydrates\% & & & & 60.25 & & 61.97 & 62.35 & Non-sign & cant & \\
\hline Proteir & & & & & 24.15 & & 25.71 & 26.56 & 0.24 & & \\
\hline$N \%$ & & & & & 3.86 & & 4.11 & 4.25 & 0.20 & & \\
\hline $\mathrm{b}-\mathrm{GA}_{3}$ & & & & & & & & & & & \\
\hline Characte & & & & & $\mathrm{GA}_{3}(\mathrm{mg})$ & & & & LSD 5\% & & \\
\hline & & & & & 0 & & 25 & 50 & & & \\
\hline Plant $\vdash$ & eight & & & & 47.58 & & 51.67 & 55.33 & 0.20 & & \\
\hline Pods $r$ & ./plant & & & & 6.50 & & 7.50 & 8.33 & 0.18 & & \\
\hline Pods v & t/plant & & & & 3.36 & & 4.81 & 5.43 & 0.36 & & \\
\hline Seeds & o/pod & & & & 7.83 & & 9.50 & 9.67 & 0.22 & & \\
\hline Seed $y$ & eld (ton/fed) & & & & 1.83 & & 2.59 & 2.87 & 0.24 & & \\
\hline Straw & ield (ton/fed) & & & & 4.39 & & 4.78 & 5.38 & 0.12 & & \\
\hline Biolog & al yield (ton/ & & & & 6.22 & & 7.37 & 8.26 & 0.36 & & \\
\hline Total c & rbohydrates\% & & & & 59.55 & & 61.92 & 63.09 & 0.40 & & \\
\hline Proteir & & & & & 23.60 & & 25.96 & 26.85 & 0.24 & & \\
\hline$N \%$ & & & & & 3.78 & & 4.15 & 4.30 & 0.16 & & \\
\hline$C-I A A+G$ & & & & & & & & & & & \\
\hline IAA (mg/l) & $\mathrm{GA}_{3}(\mathrm{mg} / \mathrm{l})$ & Plant height & $\begin{array}{l}\text { Pods } \\
\text { no./plant }\end{array}$ & $\begin{array}{l}\text { Pods } \\
\text { wt/plant }\end{array}$ & $\begin{array}{l}\text { Seeds } \\
\text { no./pod }\end{array}$ & $\begin{array}{l}\text { Seed yield } \\
\text { (ton/fed) }\end{array}$ & $\begin{array}{l}\text { Straw yield } \\
\text { (ton/fed) }\end{array}$ & $\begin{array}{l}\text { Biol yield } \\
\text { (ton/fed) }\end{array}$ & $\begin{array}{l}\text { Total } \\
\text { carbo \% }\end{array}$ & Protein\% & N\% \\
\hline 0 & 0 & 43.25 & 5.50 & 2.74 & 7.00 & 1.59 & 3.72 & 5.31 & 58.61 & 22.75 & 3.64 \\
\hline & 25 & 46.50 & 7.00 & 3.98 & 9.00 & 1.94 & 4.21 & 6.15 & 60.41 & 24.52 & 3.92 \\
\hline & 50 & 51.50 & 7.50 & 4.60 & 9.50 & 2.11 & 5.43 & 7.54 & 61.74 & 25.18 & 4.03 \\
\hline 25 & 0 & 47.50 & 6.50 & 3.36 & 8.00 & 1.72 & 4.40 & 6.11 & 59.55 & 23.69 & 3.79 \\
\hline & 25 & 53.50 & 7.50 & 4.60 & 9.50 & 2.83 & 4.75 & 7.58 & 62.69 & 26.32 & 4.21 \\
\hline & 50 & 56.00 & 8.50 & 5.23 & 9.50 & 3.08 & 5.31 & 8.39 & 63.68 & 27.11 & 4.34 \\
\hline 50 & 0 & 52.00 & 7.50 & 3.98 & 8.50 & 2.19 & 5.05 & 7.24 & 60.49 & 24.38 & 3.90 \\
\hline & 25 & 55.00 & 8.00 & 5.85 & 10.00 & 3.01 & 5.37 & 8.37 & 62.68 & 27.05 & 4.33 \\
\hline & 50 & 58.50 & 9.00 & 6.47 & 10.00 & 3.43 & 5.41 & 8.83 & 63.87 & 28.27 & 4.52 \\
\hline LSD 5\% & & 1.20 & 1.12 & 0.64 & 0.42 & 0.24 & 0.12 & 0.36 & 0.20 & 0.36 & 0.22 \\
\hline
\end{tabular}

Data in Table 5a-c indicated that IAA and/or $\mathrm{GA}_{3}$ treatments caused increases in yield and yield attributes. In this concern, Ammanullah et al. (2010) reported that plant growth substances enhance the source-sink relationship and stimulate the translocation of photo-assimilates to sink thereby helping in effective flower formation, fruit and seed development, and ultimately enhancing the productivity of crops. Abdoli et al. (2013) mentioned that IAA is the major naturally occurring auxin that increases stem elongation, cell expansion, growth rate, and yield. Gibberellins are one of the main regulators of plant growth and development, and they normally act by signaling the removal of proteins 
that repress growth thus promoting cell proliferation and elongation (Ubeda-Tomás et al. (2009). The promoting effect of gibberellic acid may be ascribed to stimulating the mobilization of nutrients toward the buds thereby increasing cell division and/or increasing the differentiation of the vascular (Chen et al. 2014). Also, the increases in the yield of mungbean plants by application of different treatments relative to untreated plant might result through breaking the apical dominance of mungbean plants leading to the increase in flowering branches and consequently the number of fruits. The increases in seed weights might be ascribed to the promotive effect of IAA and/or $\mathrm{GA}_{3}$ in increasing the assimilates and their translocations from leaves to the fruits where the seed weight increased (Mostafa et al. 2005a, 2005b; Chen et al. 2014; Mekki 2016; and Kumar et al. 2018).

Data in Table $5 \mathrm{a}-\mathrm{c}$ reveals that IAA and/GA $\mathrm{GA}_{3}$ treatments significantly increased total carbohydrate, protein, and nitrogen contents in the yielded seeds of the mungbean plant compared with the control plants. Treatment of $50 \mathrm{mg} / \mathrm{l} \mathrm{IAA}+50 \mathrm{mg} / \mathrm{l} \mathrm{GA}$ was the most effective treatment as it caused the highest total carbohydrate and protein contents of the yielded seeds. These results agree that treatments had an enhancement effect on growth, as reported in some of the findings of Ibrahim et al. (2007), Sadak et al. (2013), and Choudhury et al. (2013) on faba bean for IAA treatments and.

\section{Conclusion}

It can be concluded that treatment of IAA $50 \mathrm{mg} / \mathrm{l}+\mathrm{GA}_{3}$ $50 \mathrm{mg} / \mathrm{l}$ was an effective treatment to increase mungbean growth, photosynthetic pigments, endogenous phytohormones, yield, yield components, and chemical composition of the yielded seeds as low input technology for improving the yield of mungbean. It was a needed complementary research on mungbean as double purpose crop (forage and seed).

\section{Abbreviations}

$\mathrm{GA}_{3}$ : Gibberellic acid; IAA: Indole acetic acid

\section{Acknowledgements}

Not applicable.

Funding

Not applicable.

\section{Availability of data and materials}

Not applicable.

\section{Authors' contributions}

All authors share in every step of this work and all of them contribute to writing the manuscript. All authors read and approved the final manuscript.

\section{Ethics approval and consent to participate}

Not applicable.

\section{Consent for publication}

Not applicable.

\section{Competing interests}

The authors declare that they have no competing interests.

\section{Publisher's Note}

Springer Nature remains neutral with regard to jurisdictional claims in published maps and institutional affiliations.

\section{Author details}

${ }^{1}$ Field Crops Research Department, Agricultural and Biological Division, National Research Centre, Giza 12622, Egypt. ²Botany Department, Agricultural and Biological Division, Agricultural and Biological Division, National Research Centre, Giza 12622, Egypt.

Received: 7 February 2019 Accepted: 19 March 2019

Published online: 11 April 2019

\section{References}

Abdoli M, Saeidi M, Jalali-Honarmand S, Azhand M (2013) The effect of foliar application of Indole-3-acetic acid (IAA) and roles of ear photosynthesis on grain yield production of two wheat cultivars (Triticum aestivum L.) under post anthesis water deficit. Inter Res J Appl Basic Sci 4:1406-1413

Ammanullah MM, Sekar S, Vicent S (2010) Plant growth substances in crop production. Asian J Plant Sci 9:215-222

Atteya KG, Esmail A, Genaidy E, Zahran HA (2018) Chemical constituents and yield of Simmondsia chinensisplants as affected by foliar application of gibberellic acid and zinc sulphate. Bio Res 15(3):1528-1541

Barakat NAM (2011) Oxidative stress markers and antioxidant potential of wheat treated with phyto- hormones under salinity stress. J Stress Physiol Biochem 7:250-267

Bradford MM, 1976. A rapid and sensitive for the quantitation of microgram quantitites of protein utilizing the principle of protein-dye binding Analyt Biochem 72:248-254.

Chapman HD and Pratt PE, 1978. Methods of Analysis for Soils, Lands and Waters. Univ Calif Div Agric Sci 3043. pp: 162-165.

Chen L, Hao L, Condon AG, Hu YG (2014) Exogenous ga3 application can compensate the morphogenetic effects of the ga-responsive dwarfing gene rht12 in bread wheat. PLoS One 9(1):e86431. https://doi.org/10.1371/journal. pone.0086431

Choudhury S, Islam N, Sarkar MD, Ali MA (2013) Growth and yield of summer tomato as influenced by plant growth regulators. Int J Sustain Agric 5(1):25-28

Davies PJ (2004) Plant hormones: biosynthesis, signal transduction, action. Kluwer Academic Press, Netherlands

Dubois M, Gilles KA, Hamilton JK, Robers PA (1956) Colourimetric method for determination of sugars and related substances. Anal Chem 28:350-356

El Karamany MF (2006) Double purpose (forage and seed) of mungbean production 1-effect of plant density and forage cutting date on forage and seed yields of mungbean (Vigna radiata (L.) Wilczck). Res J Agric Biol Sci 2(4):162-165

El-Saeid HM, Abou-Hussein SD, El Tohamy WA (2010) Growth characters, yield and endogenous hormones of cowpea plants in response to IAA application. Res J Agric Biolog of Sci 6:27-31

Hopkins WG, Hünter NPA (2004) Introduction to plant physiology, 3 Ed. Wiley, USA

Ibrahim ME, Bekheta MA, El-Moursi A, Gaafar NA (2007) Improvement of growth and seed yield quality of Vicia faba L. plants as affected by application of some bioregulators. Aust J Basic Applied Sci 1:657-666

Jacobs WP (1979) Plant hormones and plant development. Cambridge Univ. Press, London, pp 104-109

Kaya C, Ashraf M, Dikilitas M, Tuna AL (2013) Alleviation of salt stress-induced adverse effects on maize plants by exogenous application of indole acetic acid (IAA) and inorganic nutrients - a field trial. Aust J Crop Sci 7:249-254

Kumar AS, Sakthivel N, Subramanian E, Kalpana R, Janaki P, Rajesh P (2018) Influence of foliar spray of nutrients and plant growth regulators on physiological attributes and yield of finger millet (Eleusine coracana $(\mathrm{L}$.) Gaertn.). Inter J of Chem Studies 6(3):2876-2879

Letham DS, Goodwin PB, Higgins TJ (1978) Phytohormones and related compounds: a comprehensive treatise. In: VIl: Phytohormones and the development of higher plants. Elsevier/North Holland, Biochemical Press Amsterdam, Oxford

Lichtenthaler HK, Buschmann C (2001) Chlorophylls and carotenoids: measurement and characterization by UV-VIS spectroscopy. In: Wrolstad RE, Acree TE, An H, Decker EA, Penner MH, Reid DS, Schwartz SJ, Shoemaker CF, 
Sporns P (eds) Current protocols in food analytical chemistry (CPFA). Wiley, New York, pp F4.3.1-F4.3.8

MacDonald H (1997) Auxin perception and signal transduction. Physiol Plant 100:423-430

Magome H, Yamaguchi S, Hanada A, Kamiya Y, Odadoi K (2004) Dwarf and delayed-flowering 1, a novel Arabidopsis mutant deficient in gibberellins biosynthesis because of over expression of a putative AP2 transcription factor. Plant J 37:720-729

Mekki BE (2016) Growth and yield of mungbean (Vigna radiata L.) in response to gibberellic acid and uniconizole foliar application. Int J Chem Tech Res 9(3):76-82

Mostafa HAM, El-Bassiouny MS, Khattab KI, Sadak MS (2005a) Improving the characteristics of Roselle seeds as a new source of protein and lipid by gibberellins and benzyladanine application. J Appl Sci Rese 1(2):161-167

Miller $L$ and Houghton JA (1945). The micro-kjeldahl determination of the nitrogen content of amino acids and proteins. J. A. J. Biol. Chem159: 373

Muller P, Hilgenberg W (1986) Isomers of zeatin and zeatin riboside in clubroot tissue: evidence for trans-zeatin biosynthesis by Plasmodiophora brassica. Physiol Plant 66:245-250

Naeem M, Bhatti l, Ahmad RH, Ashraf YM (2004) Effect of some growth hormones (GA , 3 IAA and kinetin) on the morphology and early or delayed initiation of bud of lentil (Lens culinaris Medik). Pak J Bot 36:801-809

Omer HA, El Karamany MF, Ahmed SM, Soha SA-M, Bakry AB (2017) Using field crop by-products for feeding rabbits. Biosci Res 14(2):224-233

Sadak MS, Dawood MG, Bakry AB, El-Karamany MF (2013) Synergistic effect of indole acetic acid and kinetin on performance, some biochemical constituents and yield of faba bean plant grown under newly reclaimed sandy soil. W J Agric Sci 9(4):335-344

Shah SH (2007) Effect of kinetin spray on growth and productivity of black cumin plants. Russian J Plant Physiol 54:702-705.3

Snedecor GW, Cochran WG (1990) Statistical methods 8th ed. lowa State Press, lowa

Taiz L, Zeiger E (2006) Plant physiology. 4th Ed. Sinauer Associates, Inc., Publishers, USA

Ubeda-Tomás S, Federici F, Casimiro I, Beemster GT, Bhalerao R et al (2009) Gibberellin signaling in the endodermis controls Arabidopsis root meristem size. Curr Biol 19:1194-1199. https://doi.org/10.1016/j.cub.2009.06.023

Wasfy WS, Orrin ES (1975) Identification of plant hormones from cotton ovules. Plant Physiol 55:550-554

\section{Submit your manuscript to a SpringerOpen ${ }^{\circ}$ journal and benefit from:}

- Convenient online submission

- Rigorous peer review

- Open access: articles freely available online

High visibility within the field

- Retaining the copyright to your article

Submit your next manuscript at $\boldsymbol{\nabla}$ springeropen.com 